\title{
Anti-fungal Effect of Trichoderma sps. and Botanicals against Bipolaris maydis ((Nisikado and miyake) Shoemaker) Inciting Southern Corn Leaf Blight
}

\author{
R. Hepsibah Helen Evan ${ }^{1 *}$, Sunil Zacharia ${ }^{1}$, Tage Kaku ${ }^{1}$ and B. Ravi Teja Naidu ${ }^{2}$ \\ ${ }^{1}$ Department of Plant Pathology, Sam Higginbottom University of Agriculture, Technology \\ and Sciences, Prayagraj, (Uttar Pradesh), India [RHHE, SZ, TK] \\ ${ }^{2}$ Department of Plant Pathology, Ranchi Agriculture College, Birsa Agricultural University, \\ Ranchi, (Jharkhand), India [BRTN] \\ *Corresponding author
}

\section{A B S T R A C T}

\begin{tabular}{|c|}
\hline Keywords \\
\hline $\begin{array}{l}\text { Bio agents, } \\
\text { Bipolaris maydis, } \\
\text { Botanicals, } \\
\text { Fungicide, } \\
\text { Helminthosporium } \\
\text { maydis, Maydis leaf } \\
\text { blight, Plant } \\
\text { extracts, Southern } \\
\text { corn leaf blight, } \\
\text { Trichoderma sps. }\end{array}$ \\
\hline Article Info \\
\hline $\begin{array}{l}\text { Accepted: } \\
17 \text { January } 2021 \\
\text { Available Online: } \\
\text { 10 February } 2021\end{array}$ \\
\hline
\end{tabular}

\section{Keywords}

Bio agents,

Botanicals,

Fungicide,

maydis, Maydis leaf

blight, Plant

corn leaf blight,

Article Info

Accepted:

Available Online

February 2021
Southern Corn Leaf Blight (SCLB) incited by Bipolaris maydis (Nisikado and Shoemaker) is one of the major diseases infecting most of the corn fields and a major hindrance to maize yield. In the present investigation, both in-vitro and in-vivo studies were conducted to interpret the efficacy of different concentrations of botanicals and Trichoderma sps. against $B$. maydis in managing the disease. Microscopic studies revealed that the pathogen was dark gray with grayish conidial colonies; mycelia were cottony, dull grey in colour. Conidia were having 5-8 septae, long, slightly curved with round ends and bipolar germination producing flexuous conidiophores which are light brown in colour and rose singly or in groups. Antagonistic properties were revealed among the treatments where, $T$. viridae $(85.07 \%)$ gave maximum mycelial inhibition followed by $T$. harzianum $(80.78 \%)$ and onion $(73.76 \%)$ in comparison with treated check propiconazole $(100 \%)$. Field trials during Kharif 2019, were conducted based on their efficacy in lab conditions where plots treated with $T$. viridae + FYM recorded lowest disease incidence (33.32\%), PDI (35.71\%) and maximum yield (4.30 t/ha) followed by those in plots having seeds treated with $T$. harzianum $(35.08 \%, 38.09 \%, 4.20$ t/ha respectively) followed by those in plots having foliar spray of garlic $(50.87 \%, 42.85 \%, 3.99 \mathrm{t} / \mathrm{ha}$ respectively). Highest Cost Benefit ratio was recorded in $T$. harzianum $(1: 1.74)$ and $T$. viridae $(1: 1.71)$ with better returns per rupee when compared with control (1:1.24). Thus concluding the results, field application of $T$. viridae mixed with FYM a week before sowing, seed treatment with Trichoderma harzianum and foliar spray of garlic leaf extract were found to be appropriate alternatives for managing this disease by reducing the use of chemicals.

\section{Introduction}

Maize (Zea mays L) a native of South America (Mangalsdorf, 1974; Galinat 1988), is the most versatile crop, adapted to different agro-ecological and climatic condition. Globally, maize is an important cereal crop next to rice and wheat and is called the 
"Queen of the cereals". Maize ranks third in the world after wheat and rice in area and production. However, as far as productivity is considered it ranks first. Worldwide production was around 1147.62mt (FAO, 2018) with over 193.73 mha of maize planted worldwide with a productivity of 5,923.81 $\mathrm{kg} / \mathrm{ha}$. In India, it is grown over an area of $9.20 \mathrm{mha}$, with a production of about $278.20 \mathrm{mt}$, productivity of $3,023 \mathrm{~kg} / \mathrm{ha}$ holding $24.24 \%$ of global production. Maize is very commonly used for livestock as fodder and grains are utilized for human food, poultry feed and industries for production of starch and confectionary purpose. The production and productivity of maize is declining due to biotic and abiotic stresses.

The estimated losses due to major diseases of maize in India is about $13.2 \%$ of which foliar diseases $(5 \%)$, stalk rots, root rots, ear rots $(5$ $\%$ ) cause major yield losses. Southern Corn Leaf Blight (SCLB), a fungal disease caused by Bipolaris maydis ((Nisikado and Miyake) Shoemaker) is an important foliar disease in almost all the maize growing regions of India and the world with three races of the pathogen designated as race $\mathrm{O}, \mathrm{T}$ and $\mathrm{C}$, where Race $\mathrm{T}$ is dominant in China (Wei et al., 1988) whereas race $\mathrm{O}$ is predominant in India. SCLB caused the most devastating epidemic in the Corn belts of USA in 1970 because of monoculture of cytoplasmic male sterile corn hybrids (cms-T) over large areas causing some 20-30\% loss in the yields with a monetary loss of 1 billion dollars causing the epidemic reporting this disease and pathogen for the $1^{\text {st }}$ time. In India, the maize growing regions in Uttar Pradesh, Karnataka, Andhra Pradesh, Bihar, Maharashtra, Uttaranchal and Tamil Nadu have been identified as endemic areas for the disease.

In India, it was reported for the $1^{\text {st }}$ time by Munjal and Kapoor, 1960 from Maldah, West Bengal. SCLB is one of the important and wide spread corn leaf disease around the world and it is prevalent in warm humid temperate to tropical regions, where temperatures ranges from $20-30{ }^{\circ} \mathrm{C}$ during cropping period causing significant yield losses in cultivars developed from subtropical or temperate germplasm ranging from $9.7 \%$ to $11.7 \%$ depend upon the weather conditions (Singh and Srivastava, 2012). Symptoms exhibited are small diamond shaped lesions of size 2-6 $\times 3-22 \mathrm{~mm}$, center of each was straw colored surrounded by a dark brown margin. These lesions elongate as they mature, but growth of them was restricted to leaf veins. Symptoms are sometimes confined to leaves or may extend to sheaths, stalks, husks, ears and cobs (Manamgoda et al., 2014). It is found to have high saprophytic ability (Blanco and Nelson, 1972) and areas with more diseases occurrence will be having high ranges of primary inoculums. Considering the devastating effects of this disease, studies was carried out where the efficacy of botanicals and bio-agents against B. maydis was tested even though they didn't give instant results, but are safe for use and help in reducing the usage of chemicals as their overuse is hazardous to the environment.

\section{Materials and Methods}

\section{In vitro screening of Bio agents and Botanicals against Bipolaris maydis}

The experiment was conducted in completely randomized design (CRD) in laboratory condition. Five of the botanical extracts namely onion, neem, garlic, tulsi and sarpagandha were taken each at 5, 10 and $15 \%$ concentrations along with $T$. viridae and T. harzianum and a chemical (propiconazole) 25 EC as treated check @ 0.02,0.05 and 0.1 $\%$ concentrations comparing their efficacy with an untreated control against Bipolaris maydis inciting Maydis Leaf Blight upon potato dextrose media (PDA). 


\section{Source and isolation of pathogen}

The diseased leaves from a susceptible local variety (Naveen) of maize being grown in the village around SHUATS were collected and pathogen was isolated upon PDA. Diseased portion of the leaves were cut as small bits under aseptic conditions and surface sterilized with $0.2 \%$ mercuric chloride later in $70 \%$ ethanol and sterile water. The bits were placed in Petri dishes with PDA. The inoculated plates were incubated at room temperature $\pm 28^{\circ} \mathrm{c}$ BOD until mycelial growths seen on the plates. The fungal colonies were purified by hyphal tip method and used for the whole process of evaluation both in vitro and in vivo. It has shown the same symptoms when inoculated and reisolated from the healthy maize plants.

\section{Source and isolation of Trichoderma spp.}

Soil samples were collected from the rhizospheric soils of maize fields in SHUATS. Serial dilution and spread plate technique (Sundara and Sinha, 1963) was used to isolate Trichoderma from the collected soil samples upon PDA. Five test tubes with $9 \mathrm{ml}$ sterile water in each, plugged with non absorbent cotton were numbered as $10^{-1}, 10^{-2}$ up-to $10^{-5}$ and autoclaved. $1 \mathrm{gm}$ of soil was added into the $10^{-1}$ test tube and mixed thoroughly. From this, $1 \mathrm{ml}$ of solution was taken out and added to $10^{-2}$ test tube with a fresh sterilized pipette and the same process was repeated for the subsequent test tubes until $10^{-5}$. Then $1 \mathrm{ml}$ of diluted soil solution from $10^{-5}$ test tube was taken and added to a sterilized Petri plate with PDA and the plate was titled in a rotary motion so that the solution was spread uniformly inside the plate. These plates were incubated in the BOD for a week at $28^{\circ} \mathrm{c}$ and are under regular observation for the Trichoderma growth. Pure culture of Trichoderma was obtained by hyphal tip method. The Trichoderma spp. were further identified based on morpholological keys given by Barnett and Hunter (1972) and stored up for use.

\section{Preparation of plant extracts}

Extracts were obtained from plants having fungicidal properties, ethanols and flavanoids in them like Neem (Azadirachta indica), Onion (Allium cepa), Sarpagandha (Rauvolfia serpentine), Garlic (Allium sativum) and Tulsi (Ocimum sanctum). Fresh leaves from these plants were obtained, washed with sterile water and grinded by adding equal proportions of water to leaves in weight by volume method $(1: 1 \mathrm{w} / \mathrm{v})$. The ground paste was then filtered through double layered muslin cloth. The obtained filtrate is the stock solution and was diluted further to required concentrations either in PDA or Sterile water in in-vitro and in-vivo respectively.

\section{Poisoned food technique}

PDA was amended with treatments in the conical flasks, stirred well for proper mixture and sterilized at $15 \mathrm{lb}$ pressure/ sq inch. for 15 mins. This media was further poured into sterilized Petri plates @ 20ml/plate and allowed to solidify. Pure culture of Bipolaris maydis which was 10 days old was cut into $5 \mathrm{~mm}$ disc with cork borer and was inoculated at the centre of the media plate and the plates are incubated at $28 \pm 2^{\circ} \mathrm{c}$ in BOD. Plain PDA, not amended with any of the plant extracts was used as control and everything in the count of five replicates were maintained and data was recorded for every $72 \mathrm{hrs.} \mathrm{After} \mathrm{the}$ full growth in control plate was observed, the growth of test pathogen in treated plates was measured and per cent inhibition was calculated by using the formula given by Vincent (1947).

$\mathrm{I}=(\mathrm{C}-\mathrm{T}) / \mathrm{C} \times 100$ 
Where,

$\mathrm{I}=$ Per cent Inhibition of mycelial growth

$\mathrm{C}=$ Mycelium growth in control $(\mathrm{mm})$

$\mathrm{T}=$ Mycelium growth in treatment $(\mathrm{mm})$

\section{Dual culture technique}

A culture disc of 5-mm size of the antagonist, Trichoderma spp, was placed $1 \mathrm{~cm}$ away from the periphery of the Petri dish and a same sized culture disc of the test fungus, Bipolaris maydis, was similarly placed at exactly the opposite to Trichoderma, $1 \mathrm{~cm}$ away from the edge of the Petri plate. As a control, only the test pathogen was placed in the centre of a fresh PDA plate. All pairings were carried out in five replicates and incubated at $28 \pm 2^{\circ} \mathrm{c}$. Antagonistic activity was tested after incubation when the control plate was in full growth by measuring the radius of Bipolaris maydis colony in the direction of the antagonist. The two readings were transformed into percentage inhibition of radial growth (PIRG) using the formula developed by Dickinson (1976).

$P I R G=(R 1-R 2) / R 1 X 100$

R1 - Radius of B. maydis colony in control plate

R2 - Radius of B. maydis colony in dual culture plate.

In vivo Evaluation of Bio agents and Botanicals (Plant Extracts) against Southern Corn Leaf Blight caused by Bipolaris (Helminthosporium) maydis

Field trials were conducted in Kharif 2019, to know the efficacy of plant extracts and Bio agents against the Southern Corn Leaf Blight pathogen Bipolaris maydis in randomized block design (RBD) pattern with three replications. Susceptible variety Naveen of maize was sown in fields with $75 \times 15 \mathrm{~cm}$ spacing in $2 \times 2$ sqm plot and was raised following all the agronomic practices.

\section{Artificial inoculation of maize plants}

Artificial inoculation of maize plants with pathogen was done when the plants are 28 days old by mass multiplying $B$. maydis upon sorghum grains (Carson et al., 2004). 10-20 sorghum grains infected with pathogen were placed in the whorls of maize plants. When the symptoms were observed after 7 days of inoculation, foliar treatments were sprayed at 10\% concentration twice @ 35 and 45 DAS. Bio control agents like $T$. viridae (mass multiplied on FYM was applied one week before sowing@100 gm /sqm) (Najam and Singh, 2004) and T. harzianum (seed treatment @20 gm/ $\mathrm{kg}$ ) (Ashlesha et al., 2019) were applied as prophylactic measures one week before and at the time of sowing respectively. Sterile water was sprayed in control plots. Observations on disease severity or PDI were noted down thrice during the study at 10 days interval @ 35, 45 and 55 days after sowing. Yield data was recorded during the harvest. PDI was calculated by the formula given by Wheeler (1969) following the 1 - 5 maydis leaf blight disease rating scale of Payak and Sharma (1983).

Percent Disease Index (PDI) = $\frac{0(X 0)+1(X 1)+2(X 2)+3(X 3)++_{\text {mmmom }}+n(X n)}{(X 0+X 1+\cdots \operatorname{mom}+X n) \times(\text { maximum grade })} \times 100$

(Sum total of numerical ratings/ Number of plants examined $\times$ Maximum grade) $\times 100$

Disease Incidence was visually assessed in all the plots at weekly intervals from first appearance of disease for each treatment. The mean per cent disease incidence for each treatment was obtained from the three replicates. Disease incidence was calculated by formula (Wheeler, 1969). 
Disease incidence $=($ No. of diseased plant $/$ total no. of plant examined) $\times 100$.

\section{Results and Discussion}

In vitro screening of Trichoderma sps. and plant extracts against $B$. maydis

The observations recorded In-vitro regarding the inhibitory effect of different concentrations of botanicals and the two species of bioagents upon the radial growth of test pathogen revealed that all the treatments have been found efficient. As presented in the (Table 1 and Figure 1) highest per cent inhibition was shown in dual culture technique by $T$. viridae ( $85.07 \%$ ) followed by T. harzianum $(80.78 \%)$ and among the plant extracts (Table 2 and Figure 2) at 5, 10 and $15 \%$ concentrations by poisoned food technique, onion have produced better inhibition (72.07, 73.33 and 75.90 \% respectively) followed by garlic $(69.88 \%$, 71.11 and $72.60 \%$ ) and the least inhibitory effective was tulsi (59.22, 60.55 and 62.33 $\%)$. However, among the botanical treatments at $15 \%$ concentration (T4 and $\mathrm{T} 7$ ) were found non significant and statistically at par with each other.

Table.1 Effect of Trichoderma spp. on the radial growth and inhibition of B. maydis

\begin{tabular}{|l|c|c|}
\hline Bio-control Agent & Colony Diameter (mm)* & Inhibition \% \\
\hline Trichoderma viridae (T1) & 13.43 & 85.07 \\
\hline Trichoderma harzianum (T2) & 17.29 & 80.78 \\
\hline Control & 90 & 0.00 \\
\hline Mean & 40.24 & 55.28 \\
\hline SEm \pm & \multicolumn{2}{|c|}{$\mathbf{0 . 2 7 4}$} \\
\hline CD $(\mathbf{5 \%})$ & $\mathbf{0 . 9 6 8}$ \\
\hline
\end{tabular}

*Mean of five replications

Table.2 Inhibitory effect of different concentrations of botanicals by Poisoned Food Technique upon the radial growth of $B$. maydis

\begin{tabular}{|c|c|c|c|c|c|c|c|c|}
\hline \multirow[t]{3}{*}{ Botanicals } & \multicolumn{4}{|c|}{ Growth $(\mathrm{mm}) * *$} & \multicolumn{4}{|c|}{ Inhibition Percent (\%) } \\
\hline & \multicolumn{4}{|c|}{ Concentration of treatments } & \multicolumn{4}{|c|}{ Concentration of treatments } \\
\hline & C1 $(5 \%)$ & $\mathrm{C} 2(\mathbf{1 0} \%)$ & $\mathrm{C} 3(15 \%)$ & Mean & C1 $(5 \%)$ & $\mathrm{C} 2(10 \%)$ & C3 (15\%) & Mean \\
\hline Tulsi (T3) & 36.70 & 35.5 & 33.90 & 35.36 & 59.22 & 60.55 & 62.33 & 60.7 \\
\hline Neem (T4) & 34.46 & 32.83 & 31.46 & 32.91 & 61.71 & 63.52 & 65.04 & $63.42^{\mathrm{a}}$ \\
\hline Garlic (T5) & 27.10 & 26.00 & 24.66 & 25.92 & 69.88 & 71.11 & 72.60 & 71.19 \\
\hline Onion (T6) & 25.13 & 24.00 & 21.96 & 23.69 & 72.07 & 73.33 & 75.90 & 73.76 \\
\hline Sarpagandha (T7) & 33.70 & 31.60 & 29.00 & 31.43 & 62.55 & 64.88 & 67.77 & $65.06^{\mathrm{a}}$ \\
\hline Propiconazole (T8) & 0.00 & 0.00 & 0.00 & 0.00 & 100 & 100 & 100 & 100 \\
\hline \multirow[t]{3}{*}{ Control (T0) } & 90 & 90 & 90 & 90 & - & - & - & \\
\hline & 35.29 & 32.37 & 30.47 & 32.71 & 60.77 & 61.91 & 63.37 & 62.01 \\
\hline & \multicolumn{3}{|c|}{ Treatment $(\mathrm{T})$} & \multicolumn{3}{|c|}{ Concentration (C) } & \multicolumn{2}{|c|}{ Interaction $(\mathrm{T} \times \mathrm{C})$} \\
\hline 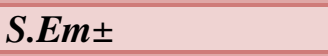 & \multicolumn{3}{|c|}{0.807} & \multicolumn{3}{|c|}{0.432} & \multicolumn{2}{|c|}{1.142} \\
\hline C.D (5\%) & \multicolumn{3}{|c|}{2.351} & \multicolumn{3}{|c|}{1.257} & \multicolumn{2}{|c|}{3.325} \\
\hline
\end{tabular}

Conc. of Propiconazole @ 0.02, 0.05 and 0.1\%, **Mean of 5 replications, G-mycelial growth in mm, I - Inhibition

Percent.

Values beside the same alphabets in the column are statistically at par with each other 
Table.3 Effect of bio- agent and botanicals on maydis leaf blight disease incidence and percent disease index

\begin{tabular}{|c|c|c|c|c|c|}
\hline T. No. & Treatments & Disease Incidence * & $\begin{array}{r}\text { PDI @ 35 DAS } \\
\text { ( Before I }{ }^{\text {st }} \text { spray) }\end{array}$ & 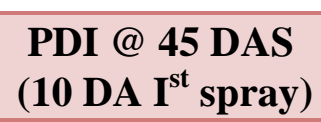 & $\begin{array}{c}\text { PDI @ 55 DAS } \\
\text { (10 DA II }{ }^{\text {nd }} \text { spray) }\end{array}$ \\
\hline T1 & T. viridae & $33.32(35.24)^{a}$ & $18.33(25.33)^{\mathrm{a}}$ & $32.80(34.94)^{a b}$ & $35.71(36.69)^{\mathrm{a}}$ \\
\hline $\mathbf{T 2}$ & T. harzianum & $35.08(36.27)^{\mathrm{a}}$ & $20.71(27.06)^{\mathrm{a}}$ & $35.86(36.75)^{b}$ & $38.09(38.06)^{a b}$ \\
\hline T3 & Tulsi & $73.68(59.08)$ & $51.27(45.69)$ & $62.76(52.36)^{d}$ & $60.95(51.30)$ \\
\hline T4 & Neem & 57.89 (49.49) & $50.17(45.06)$ & $48.92(44.37)^{\mathrm{c}}$ & $44.44(41.78)^{c}$ \\
\hline T5 & Garlic & $50.87(45.46)$ & $48.52(44.14)$ & $46.18(42.76)^{c}$ & $42.85(40.86)^{b c}$ \\
\hline T6 & Onion & $80.69(63.87)$ & $52.36(46.32)$ & $63.85(53.01)^{d}$ & $67.61(55.30)$ \\
\hline T7 & Sarpagandha & $66.66(54.70)$ & $52.26(46.26)$ & $55.92(48.39)$ & $52.38(46.32)$ \\
\hline T8 & Propiconazole & $15.78(23.34)$ & $47.13(43.34)$ & $31.50(34.14)^{\mathrm{a}}$ & $23.80(29.20)$ \\
\hline \multirow[t]{4}{*}{ T0 } & Control & $87.71(69.47)$ & $50.43(45.23)$ & $82.33(65.12)$ & $87.95(69.64)$ \\
\hline & Mean & $55.74(44.14)$ & $43.46(41.21)$ & $51.12(45.63)$ & $50.42(44.77)$ \\
\hline & SEm \pm & 1.84 & 0.94 & 1.28 & 1.81 \\
\hline & CD (5\%) & 5.51 & 2.82 & 3.83 & 5.44 \\
\hline
\end{tabular}

*values in parenthesis are arcsine transformed values.

*mean of three replications.

Values beside the same alphabets in the column are statistically at par with each other

Table.4 Effect of bio- agent and botanicals on grain yield of maize against B. maydis

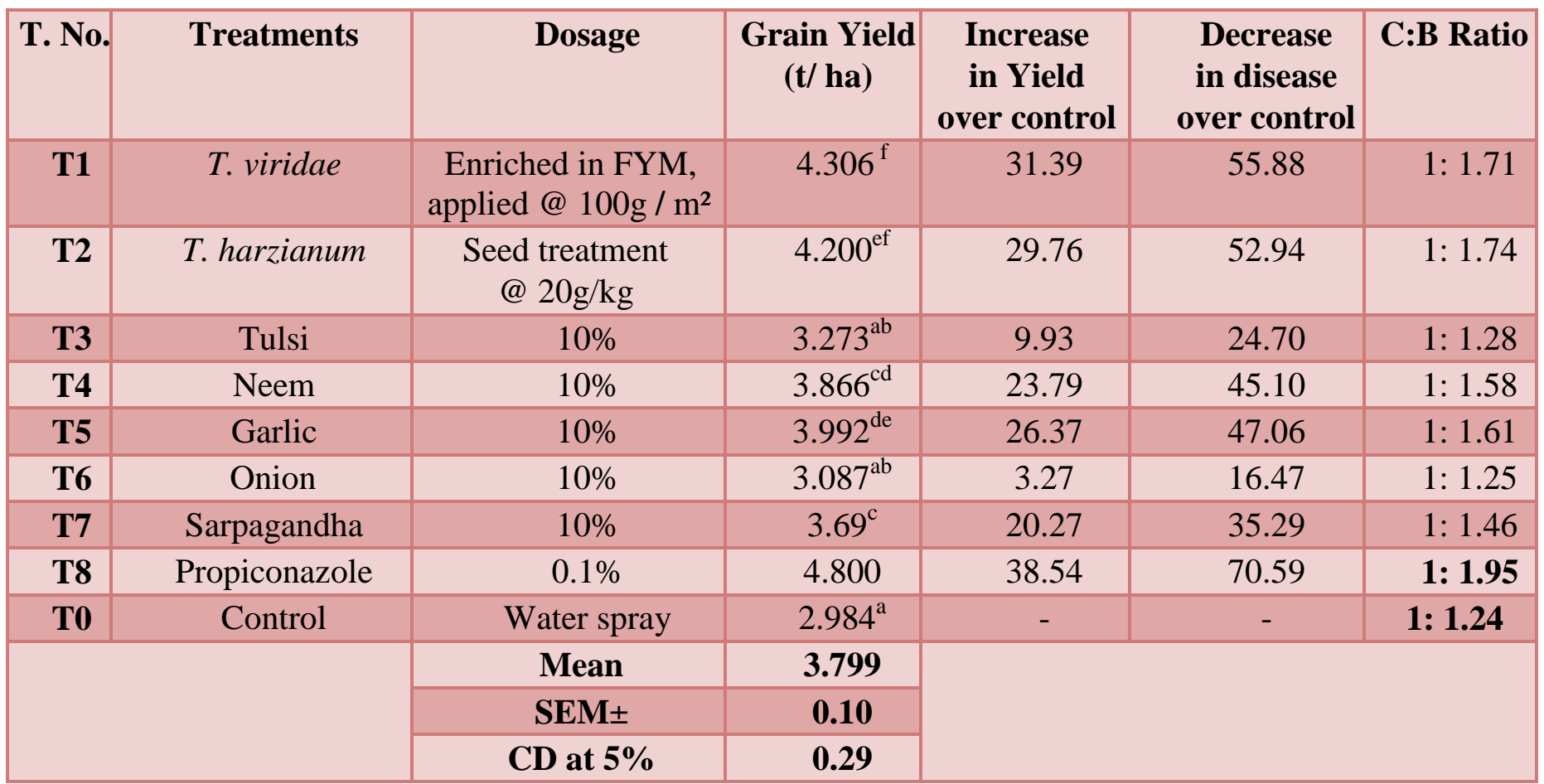

Values beside the same alphabets in the column are statistically at par with each other 
Fig.1 Mycelial Inhibition of Bipolaris maydis by Trichoderma spp.

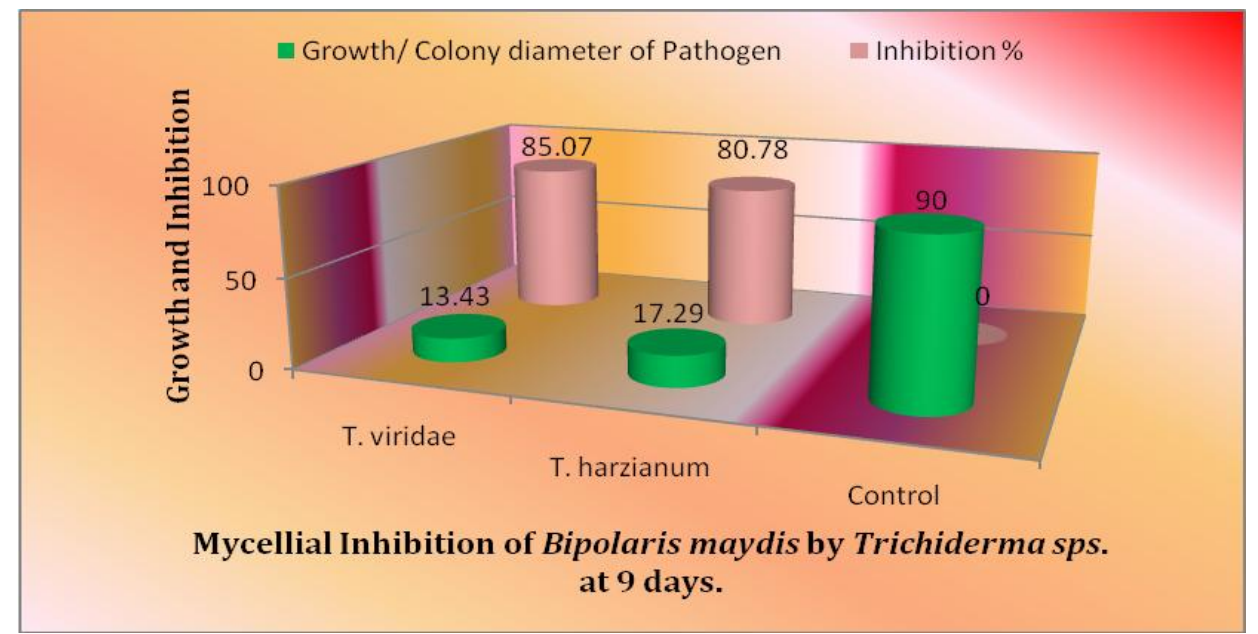

Fig.2 Effect of different concentrations of plant extracts (botanicals) upon growth and inhibition of Helminthosporium (Bipolaris) maydis

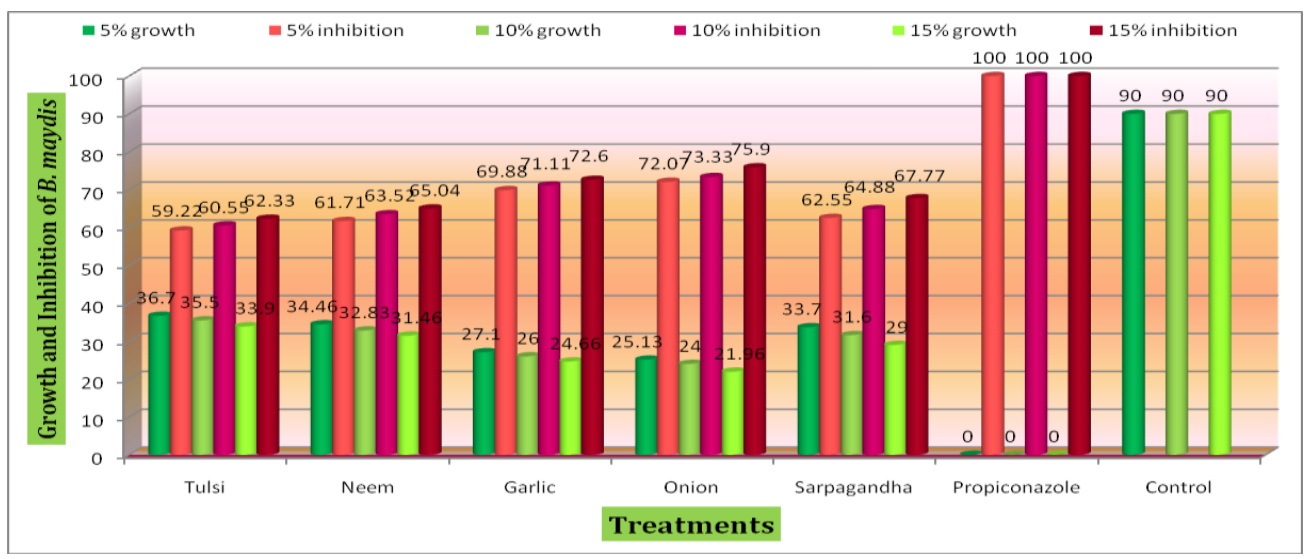

Fig.3 Effect of bio- agent and botanicals upon Incidence of Maydis Leaf Blight

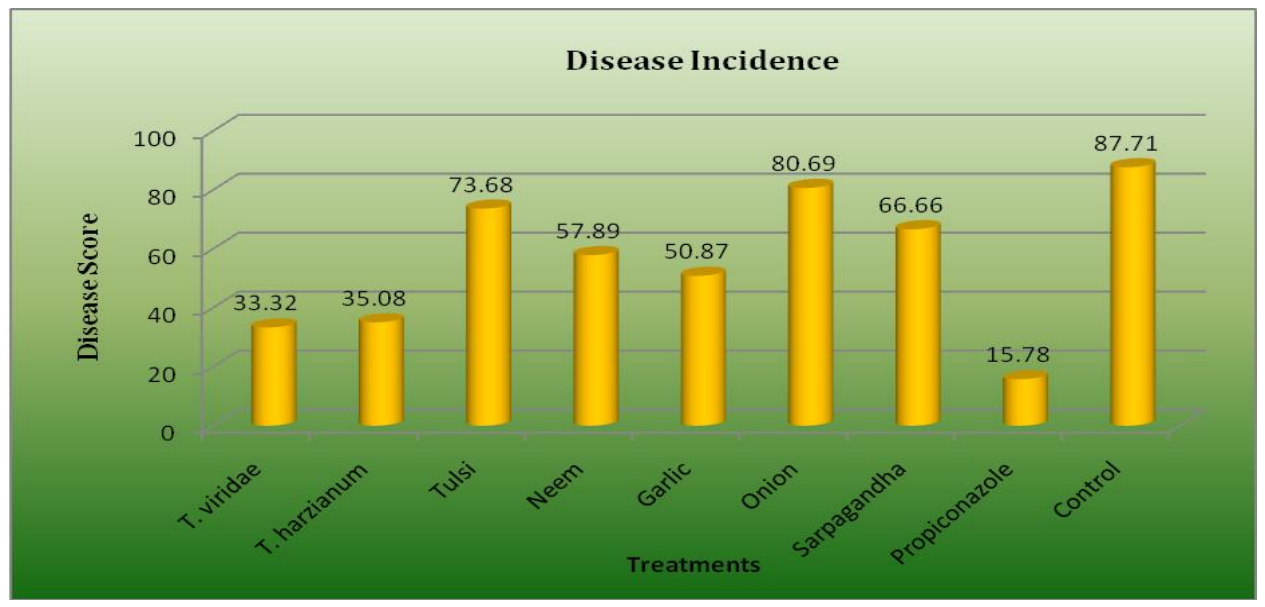


Fig.4 Effect of bio- agent and botanicals on percent disease index of Maydis leaf blight

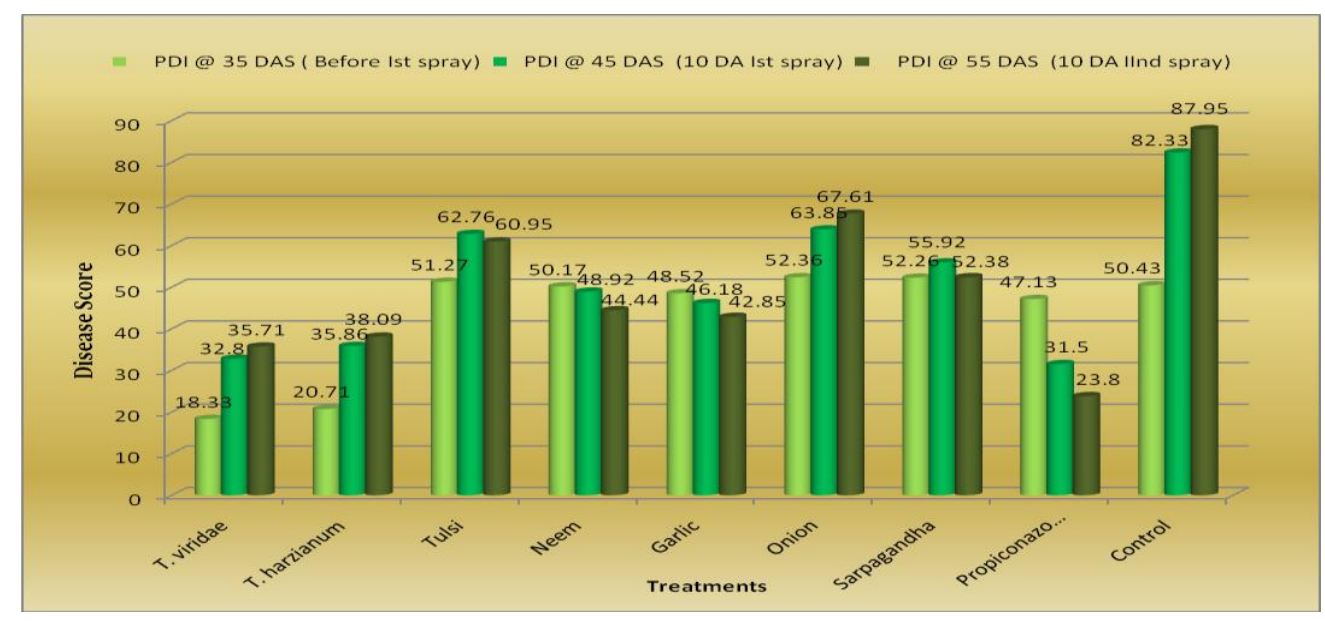

Fig.5 Effect of bio- agent and botanicals on IYOC and PDOC

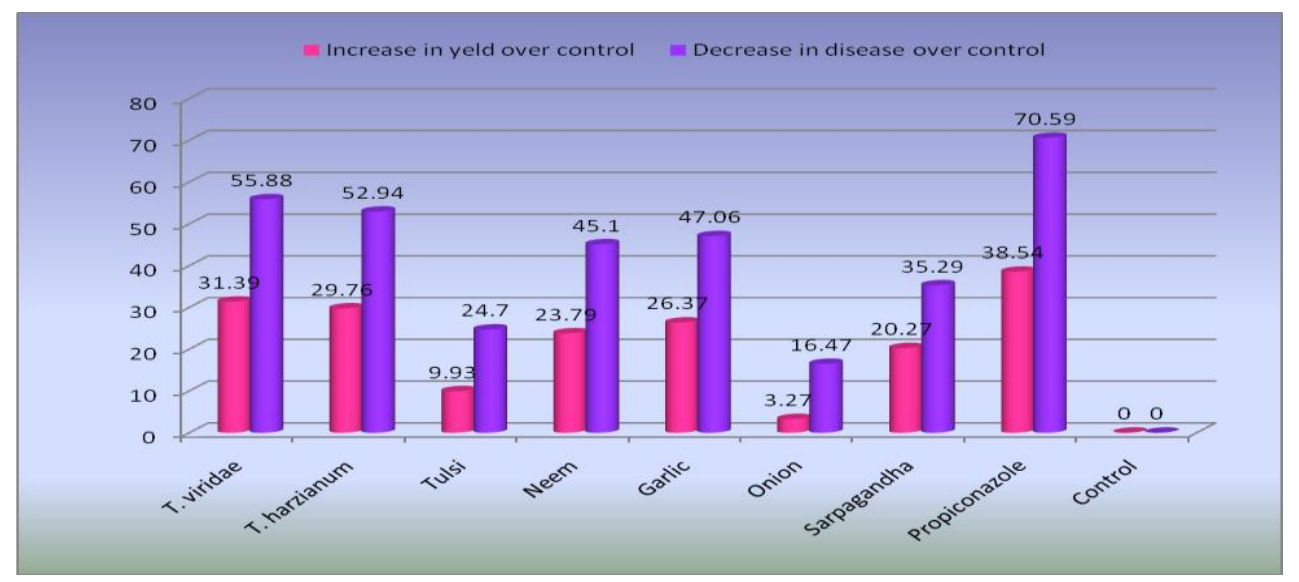

Fig.5 Effect of bio- agent and botanicals on IYOC and

Fig.6 Effect of bio- agent and botanicals on grain yield (t/ha)

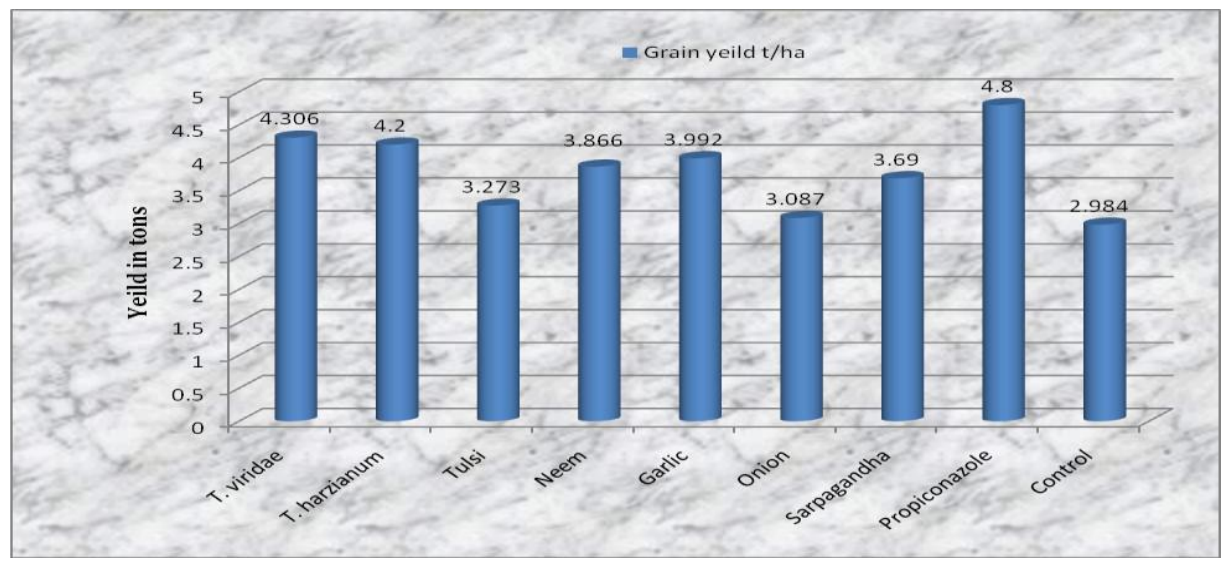


Kumar et al., (2009a) and Dash et al., (2015) reported that garlic was much efficient in inhibiting the mycelial growth of $B$. maydis which coincides with the present findings. Jha et al., (2004a) also reported that onion, neem and garlic plant extracts individually and in combination also have given inhibitory effect on mycelial growth.

In the present investigation, with respect to antagonistic potential of $T$. viridae $(85.07 \%)$ and $T$. harzianum $(80.78 \%)$, the present findings were in acceptance to those reported by Kumar et al., (2009) and Ashlesha et al., (2019) respectively.

Evaluation of plant extracts and Trichoderma spp. against Maydis Leaf Blight disease in field conditions

\section{Effect on percent disease index}

In field conditions, prophylactic application of bio agents and foliar application of botanicals at $10 \%$ concentration have been efficient in managing the pathogen and slowing down the severity of disease there by increasing the yield in those plots. The results presented in the (Table 3 and Figure 4) have revealed that the application of bio-agents before and during sowing have been more efficient in managing the disease than foliar sprays of plant extracts. The same conclusions have been drawn by Kumar et al., (2009). Among the treatments, lowest PDI noted at 35, 45 and 55days after sowing have been recorded in plots treated with Trichoderma viridae + FYM $(18.33 \%, 32.80 \%$ and $35.71 \%$ respectively), followed by seed treatment with Trichoderma harzianum (20.71 $\%, 35.86 \%$ and $38.09 \%$ respectively), Garlic (48.52\%, $46.18 \%$ and $42.85 \%$ respectively), Neem (50.17 \%, $48.92 \%$ and $44.44 \%$ respectively) when compared with treated check Propiconazole $(47.13 \%, 31.50 \%$ and $23.80 \%$ respectively) and untreated control (50.43\%, $82.33 \%$ and $87.95 \%$ respectively). Sarpagandha, Tulsi and Onion at $10 \%$ concentration have not been found so promising in their disease management efficacy. Similar results have been recorded by Kumar et al., (2009a), Kumar and Mauriya (2015) regarding the in- efficiency of Tulsi and Onion in managing the pathogen respectively.

However, when PDI @45 days after sowing was concerned, (T8 and T1), (T1 and T2), (T5 and T4) and (T3 and T6) were found to be statistically at par with each other and at PDI @ 55 days after sowing the treatments (T1 and T2), (T2 and T5), (T5 and T4) were found to be statistically non-significant to each other.

\section{Effect on disease incidence}

The data presented in (Table 3 and Figure 3) in terms of disease incidence, reveals that $T$. viridae $(33.32 \%)$, T. harzianum $(35.08 \%)$ and Garlic $(50.87 \%)$ have been way better in their ability when compared to treated check propiconazole $(15.78 \%)$ and untreated control (87.71\%). Treatment $T$. viridae (T1) have been found to be the statistically significant to the rest of the treatments in managing the disease (Fig. 5).

\section{Effect on grain yield of maize (t/ha)}

With the significant reduction in the disease severity and incidence, efficient treatments have given proportionate increase in yield when compared to untreated control. Persual of data in (Table 4 and Figure 6) reveal that $T$. viridae has given the maximum yield (4.30 t/ha), followed by $T$. harzianum (4.20 t/ha), Garlic (3.99 t/ha) and less yield when compared to others was recorded in Onion (3.08 t/ha) when compared with treated check propiconazole (4.80 t/ha) and untreated control (2.98 t/ha). In vitro and In vivo studies revealed that plant extract from Tulsi haven't been much effective which may be due to possession of less fungicidal properties or if present, they may be highly volatile.

Thus the bio-control agent Trichoderma viridae and Trichoderma harzianum. as suggested by Kumar et al., (2009) and Ashlesha et al., (2019) respectively and the plant extracts Garlic as 
reported by Kumar et al., (2009a) and Sarpagandha by Malik et al., (2018) are effective alternatives to chemicals in managing the disease and increasing the yield. Thus Use of plant products (secondary metabolites from plants) in disease management was the recent eco-friendly approach and gaining popularity because of its advantages over chemicals (Gurjar et al., 2012).

\section{Acknowledgement}

The authors and co-workers are grateful to the Head, Dept. of Plant Pathology, Naini Agricultural Institute, SHUATS for providing all the necessary facilities and co-operation to carry out the present investigation.

\section{References}

Ashlesha, Harpreet Oberoi and Parminder Kumar. 2019. "Rhizospheric Trichoderma isolates as potential bio-control agent for southern leaf blight pathogen (Bipolaris maydis) in fodder Maize." Proceedings of the Indian National Science Academy. 85.4: 885-893.

Barnett, H. L., and Hunter, B. B. 1972. Illustrated genera of imperfect fungi. Burgess publishing company. Minneapolis, Minnesota.

Carson, M. L., Stuber, C.W., and Senior, M. L. 2004.Identification and Mapping of Quantitative Trait Loci Conditioning Resistance to Southern Leaf Blight of Maize Caused by Cochliobolus heterostrophus Race O. Phytopathology. 94(8): 863.

Chandan Kumar, Miss Nudrat SanzidaAkhtar, Phool Chand and Choudary, C. S. 2019. Efficacy of Newer Fungicides against maydis leaf blight disease of maize caused by Helminthosporium maydis. Journal of Pharmacognosy and Phytochemistry. 8(6): 1553-1559.

Dash, S., Behera, S., and Behera, B. S. 2015. "Correlates of studies on helminthosporium blight of maize with special reference to management for Odisha condition." International Journal of Agricultural Science and Research (IJASR). 5.5: 439-444.

Dickinson and Skidmore. 1976.Transactions of the British Mycological Society.66: 57-60.

Galinat, W.C. 1988. The origin of corn. In: G.F. Sprauge, J.W. Dudley (Eds.) Corn and Corn improvement. American Society of Agronomy, Madison, Wisconsin, USA.132.

Gurjar, M., Ali, S., Akhtar, M. and Singh, K. 2012. Efficacy of plant extracts in plant disease management. Agricultural Sciences, 3: 425-433.

Jha, M.M., Kumar, S. and Hasan, S. 2004a. Effects of botanicals on maydis leaf blight of maize in vitro. Annals of Biology, 20(2): 173-176.

Kumar, S., and Mauriya, A. K. 2015. Effect of Fungicides and Plant Extracts for Management of Turcicum Leaf Blight of Maize. Seed. 10(56.40): 48-70.

Kumar, S., Rani, A., and Jha, M. M. 2009a. Evaluation of plant extracts for management of maydis leaf blight of maize. Annals of Plant Protection Sciences. 17(1): 130-132.

Malik, V. K., Singh, D. P., and Panwar, M. S. 2008. Management of spot blotch of wheat (Triticum aestivum) caused by Bipolaris sorokiniana using foliar sprays of botanicals and Fungicides. Indian Journal of Agricultural Sciences. 78(7): 646.

Malik, V. K., Singh, D. P., and Panwar, M. S. 2018. "Efficacy of newer molecules, bioagents and botanicals against maydis leaf blight and banded leaf and sheath blight of maize." The plant pathology journal. 34.2: 121-125.

Manamgoda, D. S., Cai, L., Bahkali, A. H., Chukeatirote, E., and Hyde, K. D. 2011.Cochliobolus: an overview and current status of species. Fungal Diversity. 51(1): 3-42.

Manamgoda, D. S., Rossman, A. Y., Castlebury, L. A., Crous, P. W., Madrid, H., Chukeatirote, E. and Hyde, K. D. 
2014.The genus Bipolaris.Studies in mycology. 79: 221-288.

Mangelsdorf Paul, C. 1974.Corn.Its origin, evolution and improvement. Belknap Press of Harvard University. $2^{\text {nd }}$ ed.273.

Munjal, R.L., and Kapoor, J.N. 1960. Some unrecorded diseases of sorghum and maize from India. Current Science. 29(11): 442-443.

Najam Waris Zaidi and Uma Shankar Singh 2004.Use of Farm Yard Manure for Mas Multiplication and Delivery of Biocontrol Agents Trichoderma harzianum and Pseudomonas flourescence. Asian Agri-History. 8(4): 297-304.

Nisikado, Y., and Miyake, C.1926.Studies on two Helminthosporiumdiseases of maize caused by $H$. turcicumPass and OphiobolusheterostrophusDrechsler (H. maydis Nisikado and Miyake). Ohara Inst. Landwrit.Forsch.Ber.3: 221-26.

Panse, V. G., and Sukhatme, P. V. (1985). Statistical methods for Agricultural workers. New Delhi, Indian council of Agricultural Research.

Payak, M.M., and Sharma, R.C. 1983. Disease rating scales in maize in India. Techniques of Scoring for Resistance to Important Diseases of Maize. All India Coordinated Maize Improvement Project, Indian Agricultural Research Institute. New Delhi. Pp. 1-4.

Reddi, T. Y., and Reddy, G. H. S.2004.Principles of Agronomy, 3 ed., Kalyani Publishers, 527.

Samuels, G. J., Petrini, O., Kuhls, K., Lieckfeldt, E., and Kubicek, C. P. (1998). The Hypocrea schweinitzii complex and Trichoderma sect. Longibrachiatum. Studies in Mycology, (41).
Sanjeev, K., Archana, R., and Jha, M. M. 2009a. Potential of Trichoderma spp. as biocontrol agents against pathogens causing maydis leaf blight of maize. Journal of Biological Control. 23(1): 8991.

Sanjeev, K., Archana, R., and Jha, M. M. 2009b.Efficacy of fungicides against Helminthosporum maydis of maize. Annals of Plant Protection Sciences.17(1): 255-256.

Sharma, R. C., Lilaramani, J., andPayak, M. M. 1978. Outbreak of a new pathotype of Helminthosporium maydis on maize in India. Note. Indian Phytopathology. 31(1): 112-113.

Singh, R., and Srivastava, R. P. 2012. Southern corn leaf blight- an important disease of maize: An extension fact sheet. Indian Research Journal of Extension Education Special Issue. 1: 334-337.

Vincent, J. M.1947.Distortion of fungal hyphae in presence of certain inhibitors.Nature.150: 850.

Warren, H. L., Jones, A., and Huber, D. M. 1977. Morphological and physiological differences between Bipolaris maydis races $\mathrm{O}$ and T. Mycologia. 69(4): 773782.

Wei, Jian-Kun, Ke-Ming Liu, Jun-Ping Chen, Pan-Chi Luo, and O. Y. L. Stadelmann. 1988. "Pathological and physiological identification of race $\mathrm{C}$ of Bipolaris maydis in China." Phytopathology. 78(5): 550-554.

Wheeler, B.E.J. 1969. An introduction to plant disease, John Wiley and fungi.Phytopathology.22: 837 - 845 .

\section{How to cite this article:}

Hepsibah Helen Evan, R., Sunil Zacharia, Tage Kaku and Ravi Teja Naidu, B. 2021. Anti-fungal Effect of Trichoderma sps. and Botanicals against Bipolaris maydis ((Nisikado and miyake) Shoemaker) Inciting Southern Corn Leaf Blight. Int.J.Curr.Microbiol.App.Sci. 10(02): 2274-2284. doi: https://doi.org/10.20546/ijcmas.2021.1002.271 